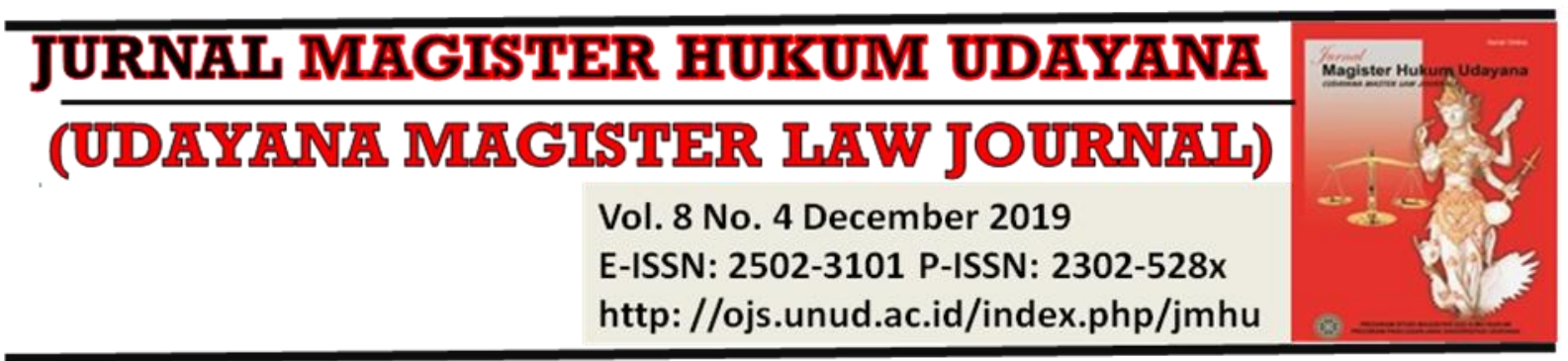

\title{
The Legal Status of Surrogacy Agreement According to Contract Law in Indonesia
}

\author{
A.A.A.Ngr. Sri Rahayu Gorda1, Ni Ketut Elly Sutrisni 2, I Gusti Agung Ayu \\ Mas Triwulandari ${ }^{3}$
}

\begin{abstract}
${ }^{1}$ Faculty of Law Pendidikan Nasional University, E-mail: srirahayugorda@gmail.com
2 Faculty of Law Pendidikan Nasional University, E-mail: ellysutrisni@undiknas.ac.id

${ }^{3}$ Faculty of Law Pendidikan Nasional University, E-mail: agungmas84@gmail.com
\end{abstract}

\begin{tabular}{l}
\hline Info Article \\
\hline Received: $23^{\text {rd }}$ October 2019 \\
Accepted: $30^{\text {th }}$ December 2019 \\
Published: $31^{\text {st }}$ December 2019 \\
Keywords: \\
Surrogacy Mother Agreement, \\
Contract Law, Legal Certainty, \\
Child Protection \\
Corresponding Author: \\
A.A.A.Ngr.Sri Rahayu Gorda, \\
Email: \\
srirahayugorda@gmail.com \\
DOI: \\
10.24843/JMHU.2019.v08.i04.p03 \\
\end{tabular}

\begin{abstract}
Indonesia does not yet have specific rules regarding surrogate mother or surrogacy agreement. The purpose of this paper is to analyze the position of surrogacy agreement according to contract law in Indonesia. It is a normative legal research that raising legal issues regarding the position of surrogacy agreement according to contract law in Indonesia. The results of the study showed that according to the elements of the legality of the agreement as stipulated in Article 1320 of the Indonesian Criminal Code, the surrogacy agreement did not fulfill the objective conditions of the agreement that entails a null and void. Besides, the surrogacy agreement did not fulfill the elements of propriety and custom and was prohibited by the Law
\end{abstract}

\section{Introduction}

The development of science and technology has contributed to the programs to have a baby with the fertilization process happening outside the mother's womb. One of them is the uterus-leasing through a surrogate mother. A husband and wife who can not have children now can opt for fertilization outside the womb by taking the egg cells (ovum) from the wife and sperm from the husband. When fertilization is successful, the embryo from the conception will be transferred to a woman (a surrogate) who is willing to bear the baby for 9 months. The husband and wife paid a certain amount of money to the surrogate mother, based on mutual agreement as monetary compensation, because she has become the surrogate mother for their baby on condition that the surrogate mother would give up the baby after birth or at the promised time. All these agreements are contained in an agreement called the Surrogacy Agreement.

Surrogacy is not a new concept-indeed. However, recent years have seen the rapid expansion of this practice, both in frequency and in geographical scope, ${ }^{1}$ including

\footnotetext{
${ }^{1}$ Katarina Trimmings \& Paul Beaumont (2011) International Surrogacy Arrangements: An urgent need for Legal Regulation at the International Level, Journal of Private International Law, 7:3, 627-647
} 
Indonesia. Specifically, a surrogate mother or surrogacy agreement does not have specific regulations in Indonesia. To find out the regulations and provisions concerning the surrogate mother and the surrogacy agreement, then it is related to several laws and regulations applicable in Indonesia. For example, how the legal status of children born from the results of the uterus-leasing. In Article 42 of the Marriage Law, it is stated that a legitimate child is a child born in or as a result of a legal marriage. Then when examining the position of the surrogacy agreement as an agreement made based on the agreement, it refers to the provisions of article 1320 of the Indonesian Civil Code relating to the legal conditions of an agreement.

The advances in technology bring changes almost in all human life, making it easier for humans to interact and communicate both in the field of business and other legal relationships, including in the field of family law related to having children. Previously, a solution for families without children was through the legal process of adoption. However, currently, the solution is growing along with the development of medical technology related to genetics. A married couple who do not yet have offspring and want their offspring to have a genetic relationship with their parents can obtain offspring through the leasing mechanism of someone else's uterus or commonly called surrogacy mother. By looking at this solution using a surrogacy mother agreement mechanism, simply from the legal aspect is within the scope of the legal agreement, especially the lease agreement. However, in Indonesian condition, Tandinerung et.al. stated that the surrogacy agreement cannot be applied in Indonesia, because the technological sophistication in the medical field has a considerable influence on society both ethics, legal norms, and religious norms. ${ }^{2}$

The rise of the practice of surrogate mothers raises many problems and this must get the attention of all parties. Based on the foregoing reasons, it is necessary to carefully examine how the existence of a surrogate mother and its implementation is regulated under an agreement called a surrogacy agreement. Based on the description above, the problems that arise can be formulated as follows: What is the legal status of surrogacy agreement according to contract law in Indonesia?

\section{Research Methods}

The research methodology used in this research is a normative juridical research method. This research is analytical descriptive, which carefully describes data or an overview about the object of the problem.

The technique of collecting legal materials is in accordance with the above research stage is by conducting a library study consisting of searching of documents on national legal instruments, laws, and regulations that have a direct relationship with the issue of surrogate mother and surrogacy agreement.

2 Tandirerung, D. A. (2018). Analisis Perjanjian Innominaat terhadap Peminjaman Rahim (Surrogate Mother) di Indonesia. Amanna Gappa, 26(1), 12-22. 


\section{Result and Discussion}

\subsection{The Legal Status of Surrogacy Agreement According to Contract Law in Indonesia}

Article 1313 of Indonesian Civil Code defines 'agreement' as "an act by which one or more persons bind themselves to one or more (s)". While surrogacy agreement is defined as a legal action between the intended parent (married couple) and surrogate mother to bind themselves to each other to have children. ${ }^{3}$

Furthermore, the agreement raises the rights and obligations of each party, namely that from the intended parent is to get a child from a surrogate mother, the surrogate mother's obligation is immediately after giving birth to the child, then the child must be immediately given to the intended parent, the right of the surrogate mother is to be funded during pregnancy until delivery by the intended parent and the intended obligation of the parent is to finance and take care of all the needs of the surrogate mother until the surrogate mother gives birth to a child.

In principle, an agreement applies to the party who entered into the agreement itself, this is a personal principle (Article 1315 and 1340 Indonesian Civil Code). The parties cannot enter into an agreement that is binding on a third party, except in what is called agreement in the interest of a third party (beding ten behoove van derden) Article 1317 of Indonesian Civil Code. ${ }^{4}$

The results of previous studies also show that in Indonesia there is no strong legal basis related to surrogate mother agreements. Arikhman, N. stated that surrogate mother still has no legal basis to be applied in Indonesian society. It is feared that the implementation will have very strong implications related to religion, ethics and other social. ${ }^{5}$ Another researcher stated that the uterine rental was a condition of a woman who was contracted or hired to conceive or raise a fetus from another woman or partner. However, the existence of sophisticated techniques in the field of medical technology and biological technology will basically affect the ethics of community life in the field of legal norms of social life and religious norms. ${ }^{6}$ Furthermore, there are those who argue that the mother surrogate technology is a solution to the problem on the one hand but it creates new problems on the other hand. One of them is the problem in the legal system in Indonesia, it also raises issues of morality and legality that were never thought of before. ${ }^{7}$ Indonesia does not yet have specific rules regarding surrogate mother, in the implementation of surrogate mother related to surrogacy agreement it is not possible to do in the jurisdiction of Indonesia, the status of children born from surrogate mother in relation to the regulation of Law No. 1 of 1974 concerning Marriage, can be considered that the child is a legitimate child of a

\footnotetext{
${ }^{3}$ Sonny Dewi Judiasih, et.al. (2016). Aspek Hukum Sewa Rahim Dalam Perspektif Hukum Indonesia, Refika Aditama, Bandung, p. 63

${ }^{4}$ Ibid., p. 65

${ }^{5}$ Arikhman, N. (2016). TINJAUAN SOSIAL, ETIKA DAN HUKUM SURROGATE MOTHER DI INDONESIA. Jurnal Kesehatan Medika Saintika, 7(2), 140-151.

${ }^{6}$ Tandirerung et.al., Op. Cit., p. 20-22

7 Wulandari, R. J., \& Darmadha, I. N. LEGAL QONSEQUENCES SURROGATE MOTHER DITINJAU DARI HUKUM PIDANA.
} 
surrogate mother, not a child of a parent who places an embryo in a surrogate mother's womb. ${ }^{8}$

The surrogacy agreement in Indonesia which is based on Article 1320 and 1548 of Indonesian Civil Code is considered null and void because it contradicts to Article 127 the Health Act. The act only gives permission for those marriage couples to do in-vitro fertilisation. ${ }^{9}$ Furthermore, the practice of surrogate mother is also prohibited under the guidelines for IVF services in hospitals by Indonesian Ministry of Health. In the regulation, it is prohibited to carry out surrogacy in any form. ${ }^{10}$

Under Article 1320 of Indonesian Civil Code, there are 4 (four) legal requirements for an agreement, and surrogacy agreement must meet the legal elements of an agreement, inter alia:

a. The consent of those who bind themselves

Mutual understanding so that an agreement can be achieved between the intended parent and surrogate mother.

b. The capability to make an agreement

Based on the age of the intended parent and surrogate mother no more than 40 years and have a healthy and strong uterus, married social status, as well as there is an agreement from her husband and as intended parent must meet the requirements that the intended parent as an egg cell donor must have a marriage status. A surrogate mother can be a person who is married and single, for a single surrogate mother, she has the right to enter into a surrogate agreement in her capacity as a legal subject. ${ }^{11}$

c. A particular object

Regarding the surrogacy agreement, which is to transfer the baby embryo into the womb of a woman who is not his wife to have a child. The object of the agreement in the surrogacy agreement is to transfer the baby embryo into the womb of a woman who is not his wife to have a child, based on Law No. 36/2009 on Health, Minister of Health Regulation No.039.Menkes / SK / 2010 concerning the Implementation of Assisted Reproductive Technology Services, Regulations Government Number 61 of 2014 concerning Reproductive Health, Fatwa of the Majelis Ulama Indonesia (MUI) on May 26, 2006, then the object of the surrogacy agreement contradicts the above regulation, a child conceived by a surrogate mother and gave up to the intended parent cannot be made as an agreement.

Under contract law applicable in Indonesia, if the surrogacy agreement does not meet the legal requirements for the 1st, 2nd, and 3rd agreements, then the legal consequences can be canceled, and the surrogacy agreement will be null and void. The elements of the agreement are the contents of the agreement itself, propriety, customs, and laws.

\footnotetext{
8 Judiasih, S. D., \& Dajaan, S. S. (2017). Aspek Hukum Surrogate Mother Dalam Perspektif Hukum Indonesia. Jurnal Bina Mulia Hukum, 1(2), 141-150.

${ }^{9}$ Risa Jaya Wulandari and I Nyoman Darmadha (2019). Legal Consequences Surrogate Mother Ditinjau dari Hukum Pidana, Kertha Wicara : Journal Ilmu Hukum, Vol. 08, No. 1, p. 4.

${ }^{10}$ David Lahia (2017). Aspek Hukum terhadap Bayi Tabung dan Sewa Rahum dari Perspektif Hukum Perdata, Journal Lex Privatum Vol. V/No. 4/Jun/2017, p. 132.

${ }^{11}$ Sonny Dewi Judiasih, Ibid., p. 66
} 
After examining the surrogacy agreement, it can be concluded that there are an agreement and the capability of the parties (parents and surrogate mothers). Whereas a certain thing here is meant object that is regulated by law and is a halal, as well as not contrary to decency and public order, so that a woman's uterus explicitly cannot be categorized as an object that can be traded and also contrary to the value of decency in society, which resulted in uterus-leasing agreements can be declared null and void. ${ }^{12}$

\subsection{Surrogacy Mother Agreement in the Contexts of Comparison in Several Countries}

The previous studies also indicated that in some countries the legal relation concerning Surrogacy Mother Agreement is still pros and cons. The comparisons of several countries regarding the legal basis of surrogacy mother as follow: based on the German Civil Code can be understood that the German state essentially bans the transfer of a woman's fetus with the aim of preparing the pregnancy for the woman from which the cell originated. Mother is the woman who gave birth to a baby. ${ }^{13}$ Even Switzerland strictly forbids surrogacy mother or it called assisted reproduction based on Article 119. France is also prohibiting surrogacy mother. In specific areas, the US recognizes Surrogacy action. ${ }^{14}$ It is also stated that other countries choose American women as women who have borrowed their wombs to give birth to their babies. However, several other states in the US argued that surrogacy is illegal, such as Delaware, Indiana, Louisiana, Michigan, Nebraska, North Dakota, Washington DC. Furthermore, previous studies also indicated that several countries pro to surrogacy mothers such as India, Australia, and Thailand, there allows surrogacy mother

Tabel 1. The comparison concerning legal Basis of Surrogacy Mother in Several Countries

\begin{tabular}{|c|c|c|c|}
\hline No & Country & Regulation & Remark \\
\hline 1 & German & $\begin{array}{l}\text { Prohibits the transfer into a woman of } \\
\text { an unfertilized egg cell produced by } \\
\text { another woman as well as the artificial } \\
\text { fertilization of an egg cell for any } \\
\text { purpose other than bringing about a } \\
\text { pregnancy in the woman from whom } \\
\text { the egg cell originated }\end{array}$ & $\begin{array}{l}\text { German Civil Code } \\
\text { Prohibit. }\end{array}$ \\
\hline
\end{tabular}

${ }^{12}$ Pinos Permana, Kontrak Lahir (sewa rahim) Dan Problematika Hukumnya, can be accessed here https://www.academia.edu/14690160/KONTRAK_LAHIR_SEWA_RAHIM_DAN_PROBLEMATIK A HUKUMNYA, Wednesday, 9 October 2019

${ }^{13}$ The IONA Institute, The Ethical Case Againts SurrogateMotherhood: What we can learn from the law of other European countries, <www.IONAINSTITUTE.IE>., p.20-23

${ }^{14}$ Seema Mohapatra, A Race to the Bottom? dalam Globalization and Transnational Surrogacy in India edited by Sayantani Das Gupta et al., Lexington Books, Plymouth ,UK: 2015, p. 149. 


\begin{tabular}{|c|c|c|c|}
\hline 2 & Switzerland & $\begin{array}{l}\text { Based on Article } 119 \text { of the Federal Act } \\
\text { Onmedically assisted reproduction } \\
\text { strictly prohibits surrogacy. } \\
\text { Article } 119 \\
\text { a. "The donation of embryos and all } \\
\text { forms of surrogate motherhood are } \\
\text { unlawful. Anyone who uses an assisted } \\
\text { reproductive technique in a Surrogate } \\
\text { Mother shall be liable to a term of } \\
\text { imprisonment or to a fine. } \\
\text { b. The same penalty shall apply to } \\
\text { anyone who acts as an intermediary for } \\
\text { Surrogate Motherhood. }\end{array}$ & $\begin{array}{l}\text { The Federal Act } \\
\text { Onmedically } \\
\text { Strictly Prohibit } \\
\text { Assisted } \\
\text { reproduction }\end{array}$ \\
\hline 3 & France & $\begin{array}{l}\text { Surrogacy agreement prohibit. } \\
\text { "All agreement relating to the } \\
\text { procreation of gestation on account of a } \\
\text { third party are void." } \\
\text { "Only things of a commercial nature } \\
\text { can be the object of conventions". }\end{array}$ & $\begin{array}{l}\text { Civil Code France } \\
\text { Prohibit Surrogacy }\end{array}$ \\
\hline 4 & Italy & $\begin{array}{l}\text { "All Surrogate Mother contracts which } \\
\text { require the Surrogate Mother to } \\
\text { consent to the third party adoption of } \\
\text { the child following birth and to } \\
\text { facilitate the transfer of child custody, } \\
\text { are null under the Italian Civil Code, } \\
\text { because the law views them as being } \\
\text { against public policy". }\end{array}$ & $\begin{array}{l}\text { The provisions of } \\
\text { the Italian Law of } \\
2004 \text { prohibit } \\
\text { Surrogate Mother }\end{array}$ \\
\hline 5 & The UK & $\begin{array}{l}\text { The UK recognized the Surrogate } \\
\text { Mother since } 1985 \text { under the Surrogacy } \\
\text { Arrangements Act } 1985 \text { which was } \\
\text { later renewed in } 2008 \text { through The } \\
\text { human fertilization and embryology } \\
\text { act in } 2008 \text {. }\end{array}$ & $\begin{array}{l}\text { The UK Surrogacy } \\
\text { Act } \\
\text { Recognize } \\
\text { Surrogacy mother }\end{array}$ \\
\hline 6 & The US & $\begin{array}{l}\text { The US recognizes Surrogacy action. } \\
\text { Surrogacy commercial can be done in } \\
\text { Alabama, Alaska, Arizona, Arkansas, } \\
\text { Colorado, Georgia, Hawaii, Idaho, } \\
\text { Iowa, Kansas, Maine, Maryland, } \\
\text { Minnesota, Missisipi, Missouri, } \\
\text { Montana, Ohio, Pensylvania, Rhode } \\
\text { Island, South Carolina, South Dakota, } \\
\text { Tennessee, Vermont, Wisconsin, }\end{array}$ & $\begin{array}{l}\text { The US recognizes } \\
\text { the } \\
\text { Mother }\end{array}$ \\
\hline
\end{tabular}


Wyoming.

However, several other states in the US argued that surrogacy is illegal, such as Delaware, Indiana, Louisiana, Michigan, Nebraska, North Dakota, Washington DC.

\section{$7 \quad$ India}

Australia
The surrogacy process can be done by a single parent or married couple, the Intended Parents process must pay all costs used during pregnancy until after the birth of the baby, the Surrogate Mother is allowed to receive compensation, but does not mention the amount of the figure specifically, the name listed on the child's birth certificate is the name of the Intended Parents and is therefore automatically considered to be the legal parent of the child.
Assisted

Reproductive Technology

Regulation Bill 2010.

Di India, surrogacy mother allows

\section{Surrogacy Mother} Australia

allows their own sperm and egg and may practice this by involving foreigners whose wombs are leased

His successor gets compensation. Including the cost of care during pregnancy, but this commercial practice cannot be done domestically unless the surrogate mother is willing not to be paid.

The purpose of uterine loan practice is allowed, provided that it is purely to help couples who want to have children

\section{Thailand}

\begin{tabular}{|c|c|}
\hline $\begin{array}{l}\text { Surrogate Mother through several } \\
\text { Invitro Fertilization clinics that provide } \\
\text { surrogate or uterine loan services. }\end{array}$ & $\begin{array}{l}\text { Thailand Surrogacy } \\
\text { Mother } \\
\text { Allows }\end{array}$ \\
\hline $\begin{array}{l}\text { Foreign couples are allowed to borrow } \\
\text { the womb from a Thai woman as a } \\
\text { surrogate mother. }\end{array}$ & \\
\hline
\end{tabular}

Source: Processed by authors from previous study sources 
By understanding those above studies it can be stated that many countries prohibit the practice of surrogacy mothers. However, a few countries allow this practice. Thailand for example very often provides the services mothers to rent out her womb. This can be seen in the services of several Invitro Fertilization Clinics in Thailand. As a result, many married couples from various countries want children with uterine services entrusted by Thai women who use these services.

\subsection{The Relevance of Surrogate Mother Arrangement in Indonesia}

Formally, the surrogate mother has not been regulated in Indonesia, but in practice, there are many behaviors that lead to surrogate mothers. For example, on the Internet, there are many young mothers from Indonesia who register as surrogate mothers.

In the future, there needs to be a clear regulation on whether surrogacy mother is allowed or prohibited in Indonesia. In the context of helping married couples who cannot have children, if surrogacy mother is permitted, then there should be at least guidelines so that there are procedures that should be carried out for the Surrogacy process so that the implementation of Surrogate Mother will be orderly and there is legal certainty for both Surrogate Mother, and those who become Intended Parents who are officially married with a proven Marriage Certificate. in the framework of public order and legal certainty, it is important that there is harmony between several related provisions such as the health law, marriage law and the agreement stipulated in the Indonesian Civil Code. The harmonization of rules that implicitly regulate the legal aspects of surrogate mother intended for the existence of order and legal certainty. The importance of legal certainty of surrogacy mother in Indonesia does not specific for the surrogacy mother and the intended parents but also for the legal status of the children.

In the context of contract law, if surrogacy mother is indeed the last solution in helping married couples who do not have children, it seems the recognition of surrogacy mother agreement can refer to the provisions of Article 1338 paragraph (1) of the Criminal Code. Of course, for the future, strict rules must be constructed that regulate the surrogate mother with the aim of creating order and legal certainty related to the civil rights of children born as well for the surrogacy mother and the intended parents.

\section{Conclusion}

Currently, in Indonesia, the practice of surrogacy mother that conducted based on the surrogacy mother agreement or contract law is not permitted because it is contrary to Article 127 of the Health Law, and Law No. 1 of 1974 concerning Marriage. However, the rises of the practice of surrogate mother in the community, give rise to the urgency of having a harmonized regulation regarding surrogate mother which is carried out based on a good surrogacy agreement between the health law, marriage law and the agreement stipulated in Indonesian Civil Code, Of course, the substance of the future law of surrogacy mother in Indonesia regulate strict requirement by considering that the agreement of surrogacy mother possible by considering that the couple married can not have a child naturally. So in this contexts, it may be creating a harmonization of related regulations that implicitly regulate the legal aspects of the practice of the surrogate mother can be as a solution because of the existing legal certainty can protect 
not only surrogacy mother and the intended parent but also the legal certainty of the child's civil status both in family and in the community.

\section{Bibliography}

$\underline{\text { Book }}$

Dewi Judiasih, Sonny Dkk. (2016), Aspek Hukum Sewa Rahim Dalam Perspektif Hukum Indonesia, Refika Aditama, Bandung

Seema Mohapatra. (2015). A Race to the Bottom? dalam Globalization and Transnational Surrogacy in India edited by Sayantani Das Gupta et al., Plymouth UK: Lexington Books

\section{Journals}

Arikhman, N. (2016). TINJAUAN SOSIAL, ETIKA DAN HUKUM SURROGATE MOTHER DI INDONESIA. Jurnal Kesehatan Medika Saintika, 7(2), 140-151. http://dx.doi.org/10.30633/jkms.v7i2.189

Judiasih, S. D., \& Dajaan, S. S. (2017). Aspek Hukum Surrogate Mother Dalam Perspektif Hukum Indonesia. Jurnal Bina Mulia Hukum, 1(2), 141-150.

Tandirerung, D. A. (2018). Analisis Perjanjian Innominaat terhadap Peminjaman Rahim (Surrogate Mother) di Indonesia. Amanna Gappa, 26(1), 12-22. http://dx.doi.org/10.20956/ag.v26i1.6335

Wulandari, R. J., \& Darmadha, I. N. (2019). Legal Qonsequences Surrogate Mother Ditinjau Dari Hukum Pidana. Kertah wicara: Journal Ilmu hukum, 8(1).

The IONA Institute, The Ethical Case Againts SurrogateMotherhood: What we can learn from the law of other European countries, www.ionainstitute.ie, p. 20-23

Pinos Permana, 2019, Kontrak Lahir (sewa rahim) dan Problematika Hukumnya, diakses https://www.academia.edu/14690160/KONTRAK_LAHIR_SEWA_RAHIM_D AN_PROBLEMATIKA_HUKUMNYA

Selian, M. A. H. (2018). Surrogate Mother; tinjauan Hukum Perdata Dan Islam. Jurnal Yuridis, 4(2), 131-147. http://dx.doi.org/10.35586/.v4i2.255

Wijaya, N. A. P., \& Purwanto, I. W. N. SURROGATE MOTHER MENURUT HUKUM DI INDONESIA. Kertha Semaya: Journal Ilmu Hukum.

\section{Legal Document}

Kitab Undang-Undang Hukum Perdata

Undang-Undang Nomor 1 Tahun 1974 tentang Perkawinan, LN Republik Indonesia Tahun 1974 Nomor 1, TLN Nomor 3019

Undang-Undang Republik Indonesia Nomor 36 Tahun 2009 tentang Kesehatan, LN Tahun 2009 Nomor 144, TLN Nomor 5063

Peraturan Menteri Kesehatan No.039.Menkes/SK/2010 tentang Penyelenggaraan Pelayanan Teknologi Reproduksi Berbantu,

Peraturan Pemerintah Nomor 61 Tahun 2014 tentang Kesehatan Reproduksi,

Fatwa Majelis Ulama Indonesia (MUI) pada tanggal 26 Mei 2006 